\title{
Factors Affecting Online Purchase Intention: Effects of Technology and Social Commerce
}

\author{
Jayani Chamarika Athapaththu ${ }^{1}$, D. Kulathunga ${ }^{2}$ \\ ${ }^{1}$ Faculty of Management and Finance, University of Colombo, Bauddhaloka Mawatha, Colombo, Sri Lanka \\ ${ }^{2}$ Faculty of Management Studies and Commerce, University of Sri Jayewardenepura, Gangodawila, Nugegoda \\ Sri Lanka \\ Correspondence: Jayani Chamarika Athapaththu, Faculty of Management and Finance, University of Colombo, \\ Bauddhaloka Mawatha, Colombo, Sri Lanka.
}

Received: August 29, 2018

doi:10.5539/ibr.v11n10p111
Accepted: September 18, 2018

Online Published: September 25, 2018

URL: https://doi.org/10.5539/ibr.v11n10p111

\begin{abstract}
With the rapid development of information communication technologies and enhanced Internet penetration, the nature of a consumer's daily activities has changed and most offline activities have migrated towards online activities. Moreover, customers have shown a greater tendency to shift to online activities from their traditional offline activities. In this light, e-commerce transactions in Sri Lanka are expected to grow in the near future. Apart from traditional Internet technologies, a variety of new social commerce activities has started influencing the behavior of customer activities including the online purchasing. Even though the impact of traditional Internet technologies on purchase intention of customers has been examined by many researchers, the same has not been examined adequately in relation to social commerce related activities. Therefore, this study is aimed at identifying the factors affecting online purchase intention of customers from both the technological and social commerce perspective.

The theoretical model developed in the study was empirically tested through survey of 292 MBA students from two leading universities and a prominent institute in Sri Lanka. Structural Equation Modeling (SEM) was used to analyze the data. The study revealed that online purchase intention positively and significantly related with perceived usefulness, perceived ease of use, website content and trust.

Moreover, it was identified that trust has a full mediation effect between perceived ease of use and purchase intention as well as between website content and purchase intention. Further, it was found that trust has a partial mediation between perceived usefulness and purchase intention.
\end{abstract}

Keywords: Technology Acceptance Model (TAM), website content, e-commerce, online purchase intention, Sri Lanka

\section{Introduction}

With the development of Information and Communication Technology (ICT) the Internet has become part and parcel of everyday life of human beings and many traditional offline activities have migrated to online environments. Thus online shopping has become popular and also an integral part of consumer life.

The emergence of the Internet has increased consumer ability to shop in any location, at any time, and purchase any number of items with ease by comparing features, value and prices before actually making in-store purchases. During the year 2016, in Sri Lanka, the Internet penetration has increased by $30 \%$ and total Internet users were boosted up to 6.1 million due to the 1.5 million cellular mobile connections and more than 300,000 broadband and dial-up Internet connections. That has led to an increase in Sri Lankans' presence on social media, particularly on Facebook, the favorite local social network, and on other online activities such as e-commerce (Colombo digital marketers 2017).

According to a recent comprehensive report published by Kayamu, e-commerce transactions in Sri Lanka are expected to grow by more than $72 \%$ in the near future (Khan 2017). According to this study, electronics and mobile phones are the major product segment in online shopping. Further, the study has shown that Sri Lankan online shoppers are more interested in searching and buying apparel and accessories, also for searching for used vehicles and employment opportunities. 
In the context of e-commerce, many research studies have been done in various areas such as online consumer behavior (Cheung, Chan \& Limayem 2005; Koufaris 2002; Bellman, Lohse \& Johnson 1999), online purchase intention (Ling, Chai \& Piew 2010; Brown, Pope \& Voges 2003; Van der Heijden, Verhagen \& Creemers 2003), website design features (Hausman \& Siekpe 2009; Cyr, 2008; Baloglu \& Pekcan 2006; Rosen \& Purinton 2004) and social commerce (Ng 2013; Curty \& Zhang 2013; Shen 2012; Grange \& Benbasat 2010). However, there is a dearth of such studies done in the Sri Lankan context, and therefore, with the rise of Internet penetration, it is important to identify the factors influencing online purchase intention in online retail shopping, since e-commerce trends have moved mainly towards online retail shopping (Khan 2017).

Thus, this study, specifically, investigates factors affecting online purchase intention using two different perspectives: a technology-oriented perspective and a social-oriented perspective. In the context of this study, the technology oriented perspective focuses on the technology requirements for conducting a transaction online, while the social perspective focuses on the information obtained from the community.

\section{Theoretical Background}

\subsection{Technology Acceptance Model (TAM)}

A website is a product of an information technology, as such, online purchase intention should be explained as part of the Technology Acceptance Model (TAM). The TAM was first developed by Davis to clarify the user response of the technology in the working environment (Davis 1989). The model suggests that based on certain beliefs, a person frames an attitude to a specific object, on the premise of which he/she shapes an intention to behave with respect to that object. Therefore the intention to behave is the major element of the actual behavior. Davis formulated the model based on the Theory of Reasoned Action (TRA), by specifying two key beliefs that specifically explain of technology usage. The first of these beliefs is perceived usefulness (PU), and the second is perceived ease-of-use (PEOU). Thus, PU and PEOU are the factors that influence the decision to use when the users are engaged with a new technology and when they use it.

The original TAM model is empirically validated in a variety of settings, specifically in the context of Internet usage and website usage. Through these various studies researchers have confirmed the relevance and suitability of PEOU and PU in an online context (Moon \& Kim 2001; Lederer et al. 2000; Teo et al. 1999).By considering the online shopper as a computer user and by treating the web store as a technology system, TAM has been used to test user intention to use the web store (Koufaris 2002). Indeed, online shoppers need to cooperate with technology to purchase the goods and services they need.

\subsection{Website Content}

While, online transactions are conducted from a technological point of view, and in doing so, researchers have emphasized the importance of a website as well. In order to conduct a transaction online, in each process requires consumers to use Internet technologies to interact with the web site. Hence, the quality of the website plays a major role in buying and selling activities. Wolfinbarger and Gilly (2003) explained that when the customers interact with the web store they are likely to perform such activities by interacting with technology rather than by obtaining support from the employees. Therefore, the website, which acts as an interface, plays an essential role in online shopping.

As indicated by Ranganathan and Ganapathi (2002), the website signifies the manner in which the substance is organized in the site. It is mainly focused on how information is arranged on the website. The structure denotes the way how information is organized within the website; for instance, hierarchical, network etc. However, Huizingh (2000) defined content to be how information, features or services are designed within the site and are made accessible to visitors. Both definitions have been operationalized by various measures in order to identify insights. According to $\mathrm{Wu}$ et al. (2013), the elaboration of the product information and images on the website are denoted as a layout design. In the present study, website content is defined as "the information, features, or services that are offered on the website" in line with past studies on website content.

Information search and evaluation are two major steps, out of several, in the consumer buying process. Each step provides valuable information to the customers for their buying and selling decisions (Ranganathan \& Ganapathy 2002). Therefore, the content of the B2C website plays a major role in the e-commerce context, since it influences the buyer's decision making process. Web surfers can be classified into different groups; customers, potential customers, suppliers, and competitors. However, the information needs on each group are different and they all may need to access the website in order to obtain different types of information. For example B2C websites provide more information than merchandise to customers. As indicated by Angehrn (1997), providing information is the fundamental objective of a website. Before buying an item, customers search for information 
on it such as: brands, assortment, cost, and quality. Yet, different customers have distinctive information needs. The amount of information provided by the B2C website should be sufficient for customers to make decisions, and conversely, the site should not be overloaded, since this will result in more information than the customer can comfortably process (Huizingh 2000).

\subsection{Trust}

Trust is clearly essential in the relationship improvement process; however, it remains a troublesome idea to define. In the e-commerce context, trust is an important determinant, since it has appeared to influence the reception of new advances, including the Web (Fukuyama 1995). There is no consensus among authors as far as the definition of "Trust" is concerned. It has been defined in different ways by different authors in different contexts. The present study limits itself to only B2C e-commerce. According to Droege, Anderson and Bowler (2003), trust means the feeling of trusting belief. Some other authors define trust as an attitude regarding another person (i.e., a feeling between trustor and trustee) (Yoon 2002; Mayer \& Davis 1995). Ganguly, Dash and Cyr (2010) defined trust as the perceived integrity and benevolence of the online store according to the view of the customer. According to Bhattacharya, Devinney and Pillutla, (1998) and Sheppard and Sherman (1998) trust occurs in an ambiguous and risky environment, and it generates a sense of predictability. Kim, Xu and Koh (2004, p.13) characterize trust as the "belief that the other party will carry on in a tried and true way in a business environment." In this study the researcher focuses on institutional trust i.e., "an individual perception regarding the e-commerce website". Thus, the present study focuses on the web retailer, arguing that in most cases, consumer trust depends heavily on the actions of web retailers.

According to Cheskin's study (1999, as cited Yoon, 2002) in an online environment, consumers pass through three stages of trust. In the initial stage, trust is established through controlling personal information and information related to search results. The second stage encompasses trust confirmation by ensuring the security of the information. Both extrinsic and intrinsic trusts rely on this stage to relate to the purchase intention. For example, in order to build up trust, symbols such as VeriSign or Visa can be used. Hence, displaying the third party authorization increases the trust in the web store. By displaying such symbols on the website, the web owner tries to signal the quality and assurance of the website. Third party assurance confirms that the vendor will behave in an ethical manner by permitting the safety of online transactions (Shankar, Urban \& Sultan 2002). The process of the development of trust ends with maintaining the gained security. At this stage, visitors are more concerned about brand and search mechanism technology which eventually results in intrinsic trust as part of the purchase intention.

\subsection{Social Commerce}

In networked digital media, the environment introduces new difficulties for individuals when they need to find information which they can trust. Commonly when people make judgments, they seek information from various external sources (e.g., experts, opinion leaders) and reduce uncertainty about credibility (Metzger \& Flanagin 2013). As such, people do not rely on one particular source or internal information only. According to recent research findings (Kim,Sin \& Tsai 2014), people use external sources such as social media for information seeking purposes. Consequently, Social Identity Theory (SIT) suggests that the information coming from group members is more credible than that are coming from out-group members (Tajfel \& Turner 2004). Thus, with the rapid improvement of web-based social networking, people increasingly seek information through social media in order to make commercial decisions. Web 2.0 has made the possibility to change web based business from a product focused environment to a social focused environment. (Wigand et al. 2008). Fundamentally, web-based social networking refers to Internet based applications worked in the light of Web 2.0, while Web 2.0 refers to a conception as well as a platform for linking shared intelligence (Kaplan \& Haenlein 2010).Thus Web 2.0 technologies and tools are being applied to engage people in sharing interests, with or without real-life connections. In this light, social commerce (s-commerce) has become a new type of electronic commerce that includes utilizing web-based social networking bolsters, social association and client commitments to aid web based buying and selling activities (Shen \& Eder 2013). When customers intend to purchase a product and or service, they usually display different decision-making behaviors mostly influenced by other people. Thus, social media provides a discussion platform for customers to take decisions (Afrasiabi Rad \& Benyoucef 2011). In this condition, shoppers can have access to social media and obtain support for their online buying decisions and to gain more information on online shopping ( $\mathrm{Ng} 2013$; Hajli 2014; Hausman \& Siekpe 2009; Kim \& Srivastava, 2007).

Different authors defined s-commerce in different viewpoints. Liang et al. (2011) defined s-commerce as the delivery of buying and selling activities via social media, which appeared through web 2.0 technologies. From the view of sociology, s-commerce is tied with using online social groups by web based business organizations, concentrating on the effect of social impact which shapes the collaboration among consumers (Kim \& Srivastava, 2007). Form the 
view of psychology, Marsden (2009) defined s-commerce as people influenced for the silent information which are generated from people within the network community for online buying and selling activities.

The customer experience in offline and online context is different from each other. In an offline context people can talk with each other can create social interactions. But in online setting customers do not have such interactions and sociability (Gefen, Karahanna \& Straub 2003). Moreover, in online context the connection between owner and shopper is unidentified, impersonal as well as computerized (Wang \& Emurian 2005). Whereas in an offline context, customer can cooperate with the staff. In online context that is a key challenge to creating such socially rich environment (Kumar et al. 2010; Park, Lee \& Han 2007). But web technologies and social technologies can impact on social insight of the customers. To do so people use social commerce constructs such as forums and communities, ratings, reviews and recommendations (Hajli 2012). These online tools help to share information and resources with friends and the members in the online community. However, anecdotal evidence suggests that social media is altering opinions and influence for decision making process of both customers as well as the online retailers (Hajli 2013; Ng 2013). Peer pressure which is created by social media is broader than anything experience in the traditional environment (Hajili 2013). Thus, social media impacts decision-making by making through network connections.

\subsection{Purchase Intention}

Purchase intention of the online shopper is the final stage, after various prompts of the online shopper. Similarly, according to Pavlou (2003), the final stage of online transaction is intention to use a website and purchase a product. Therefore, online purchase intention plays a vital role in online consumer behavior. As per, Raza et al. (2014), purchase intention means, a condition between the customer and the seller when the customer is ready to make a deal with the seller. Keller (2001), defined purchase intention as a shopper's desire to purchase an item or service since the shopper has an intention to find a specific item or benefit or a positive mind towards, even view of the product or service. In the present study purchase intention is defined as "Consumers' willingness to buy a product or service from a particular website". However, once a consumer selects a product, the final decision of purchase will depend on consumers' intention.

Purchase intention process starts with the product evaluation. To do the evaluation individuals use their current knowledge, experience and external information (Bukhari et al. 2013). Hence, external factors also play a major role in purchase intention process by influencing on consumers' attitudes. In general many factors influence on purchase intention. According to Cronin et al. (2000) both the structure of the model and information search impact on purchase intention.

The conceptual framework (Figure 1) of the study is developed based on a solid literature review and the relationship illustrated above. The framework depicts the seven hypotheses explained and identified above. The framework also highlights the two concepts: "Technology-oriented perspective" and "Social-oriented perspective" examined in this paper. The corresponding hypotheses are listed and justified below.

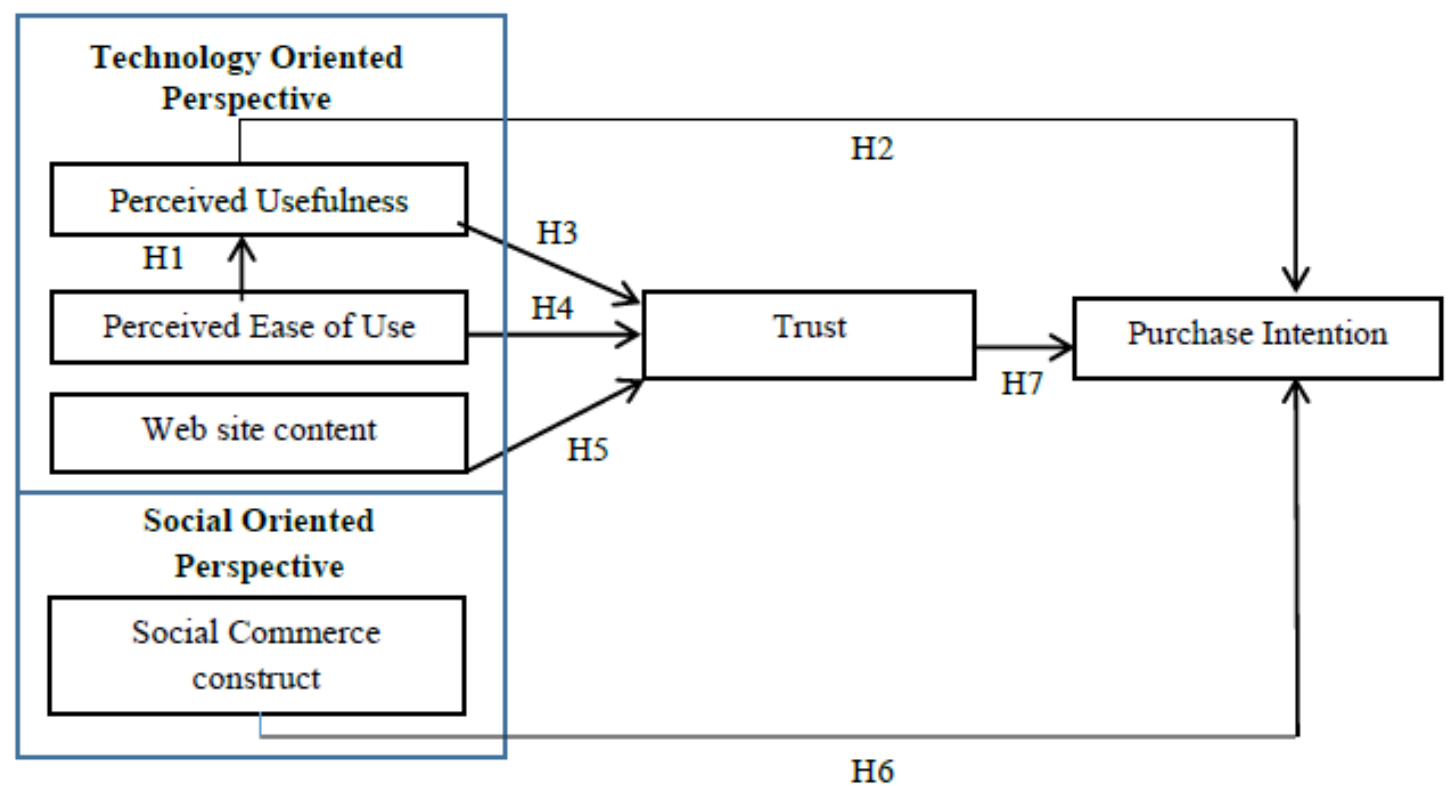

Figure 1. Conceptual framework 


\section{Hypotheses Development}

\subsection{Relationship between PEOU and PU}

The modified TAM proposed by Davis (1989), shows that PEOU indirectly influences intention through PU while, PU directly influences to the intention. Similarly, through an empirical study, Gefen and Straub (2000) broadly discussed the same relationship by explaining that in most cases PEOU influences on intention through PU. Observations on a similar theme were obtained by Pavlou (2003) who stated that PEOU has an impact on $\mathrm{PU}$, and both have direct significant impacts on B2C e-commerce. Several other studies also have confirmed the same relationship, i.e. that PEOU influences PU (Hassanein \& Head 2007; Hsu \& Lu 2004) in the e-commerce context. Consequently, the following hypothesis can be developed.

$\mathrm{H} 1:$ There is a positive effect of PEOU on PU.

\subsection{Relationship between PU and Purchase Intention}

There are several research findings which show that PU directly influences purchase intention in the e-commerce context (Gefen, Karahanna \& Straub 2003; Gefen \& Straub 2000). The findings of Dash and Saji (2006) revealed the significant direct relationship between PU and purchase intention of B2C online shoppers in an Indian context. Further, the same relationship is confirmed by Koufaris (2002), who's results show a positive relationship between PU and purchase intention in the online context, by examining the online consumer's intention to make unplanned purchases from an e-commerce context. Similarly, a notable source of support for the above findings emerged from the observations of Pavlou (2003), who confirmed the relationship between PU and purchase intention by testing the model using two different empirical studies. Therefore, the following hypothesis is developed:

H2: There is a positive effect of PU on purchase intention.

\subsection{Relationship between PU and Trust, and PEOU and Trust}

When consumers feel that the website they are patronizing is easy to use, it increases their interests in shopping online, and in using that particular website (Koufaris 2002). The study of Li,Kim and Park (2007), found that there is a significant relationship between PEOU and Trust which influences purchase intention. Similarly, Chen and Barnes (2007) stressed that PU and PEOU are significant predecessors to the creation of online trust and, that affects purchase intention positively. Carlos Roca, José García \& José de la Vega (2009) revealed that PU and PEOU are vital concerns in online trading processes. In the meantime Carlos Roca, José García \& José de la Vega (2009) illustrated that PU and PEOU are major antecedents of online trading services mediated by Trust. Various other studies have also intimated that there is a substantial effect between PEOU and purchase intention mediated by Trust (Li, Kim \& Park 2007; Gefen, Karahanna \& Straub 2003). Consequently, this study can hypothesize that:

H3: There is a positive effect of PU on Trust.

H4: There is a positive effect of PEOU on Trust

\subsection{Relationship between Web Site Content and Trust}

Several researchers' empirical results revealed that information content generates trust in the website, if the information is accurate, relevant and up-to-date (Mithas et al. 2006; Corritore et al. 2005; Yoon 2002). Furthermore, some valuable functions that a web site presents, such as information content and decision making aids which lead to the creation of consumer trust in the web store (Chen \& Barnes 2007). Additionally, when customers are comfortable with a web site, it will lead to greater trust in the customers' mind and, consequently a higher likelihood for online shopping (Roca et al. 2006). In the e-commerce context, website content exemplifies the information that is placed on the webpage, while structure exemplifies that the way in which such information is arranged (Ganguly, Dash \& Cyr 2010). As far as the arrangement of information content of the website is concerned, information design plays a major role in $\mathrm{B} 2 \mathrm{C}$ e-commerce. A notable source of support for the above findings emerges from the observations of Cyr (2008). Cyr has provided empirical findings on how information design creates a strong positive effect on Trust. Similarly, Ranganathan and Ganapathy (2002) have empirically validated the fact that website design positively influences purchase intention. Similarly, several authors have empirically confirmed that useful and easily understood information reduces asymmetric information and increases online trust thereby influencing purchase intention positively (Cao et al. 2005; Park \& Stoel 2005; Koufaris \& Hampton-Sosa 2004; Kuo et al. 2004). Insufficient, inaccurate and unreliable information presented in the web stores lead to the deterioration of customer trust in online shopping and consequently reduce the customer relationships (Wen 2009). Besides, the quantity of product collections and the accuracy of 
product explanations as well as transaction security on a web site also positively impact satisfaction and trust in the site (Yoon 2002). In addition, most websites publish their policies, promising statements and company information with the aim of increasing company credibility, which will subsequently increase customer trust in B2C e-commerce (McGinity 2000).Consequently, the following hypothesis can be developed:

H5: There is a positive effect between website content and Trust.

\subsection{Relationship between Social Commerce Constructs and Purchase Intention}

Several studies have shown that social commerce constructs including forums and communities, ratings and reviews, referrals and recommendations directly influence purchase intention (Zamrudi, Suyadi \& Abdillah 2017; Soleimani et al. 2016; Hajli 2014; Bai, Yao \& Dou 2015). According to the findings of Hajili (2014), consumers individually reach for each dimension of the SCC's and consequently use those dimensions to help them in making purchase decisions. According to observations by Chen and Xie (2005), third party reviews greatly influence consumer buying decisions. Similarly, several other studies reveal that the quality of reviews affects purchase decisions as well, especially in the initial stages of introduction of the products and services (Cui, Lui \& Guo 2012; Park, Lee \& Han 2007). Senecal and Natel (2004) also confirmed that online recommendations strongly impact on online purchase intention when customers do not have prior experience in online shopping. Ratings and reviews help buyers to search their colleagues' reviews and therefore such reviews directly influence their buying decisions. According to the findings of Ridings and Gefen (2004), the main purpose of joining online communities is sharing information. Thus, online communities have a direct influence on

buying decisions. Through the active participation of such online communities, customers can expand their knowledge and consequently help to solve their problems and make more accurate buying decisions. (Kang, Tang \& Fiore 2014). Consequently, the following hypothesis can be developed:

H6: There is a positive effect of the social commerce construct on Purchase intention.

\subsection{Relationship between Trust and Purchase Intention}

Many researchers have stated that trust is a key factor that has a significant impact on purchase intention. However, in Jarvenpaa and Tractinsky (1999)'s research, trust is mentioned as having an indirect impact on purchasing intention. Trust lessens the social complexity that the customer faces in online shopping by motivating business activities (Gefen, Karahanna \& Straub. 2003). Some other researchers have highlighted the significant relationship between trust and purchasing intention ( $\mathrm{Li}, \mathrm{Kim} \&$ Park 2007). Further several other studies have shown that online trust positively influences a customer's attitudes towards online purchase; the positive attitude thus generated has a direct effect on his/her purchase intentions (Wang 2002). Similarly, Several other studies have also confirmed that online trust positively influences purchase intention. (Gefen \& Straub 2000; Grabner-Krauter \& Kaluscha 2003; Pavlou 2003; Yoon 2002). As these researchers suggest (Jarvenpaa, Tractinsky \& Saarinen 1999) a buyer's intention to buy from an online retailer is dependent on that consumer's attitude towards the online store. This attitude is shaped by the vendor's ability to obtain the customer's trust. Consequently, the following hypothesis can be developed:

H7: There is a positive effect of Trust on Purchase intention.

\section{Research Method}

\subsection{Questionnaire Development}

The main data collection tool of this study is the questionnaire survey. All questions used in the study were adapted from pretested questions used by other researchers (for example, Li, Kim \& Park 2007; Gefen, Karahanna \& Straub 2003; Van der Heijden, Verhagen \& Creemers 2003; Pavlou 2003; Sultan et al. 2003). Questions were measured on a five point Likert scale that ranged from "Strongly agree" (for number 5) to 'Strongly disagree" (for number 1) as given in the original questionnaire (See Annexure 01). Multiple items were used to measure all the constructs and respondents were asked to answer the questions based on their last online purchase experience by following the study of Gefen, Karahanna, and Straub (2003).

\subsection{Data Collection and Sample}

The study of empirical research on online trust done by, Grabner-Krauter and Kaluscha (2003) shows that majority of research works utilize by the undergraduate and/ or MBA students as their subject pool. Walczuch and Lundgren (2004) also argued that the post graduate student is the most appropriate unit of sample for e-commerce research, since she/he, has an opportunity to use the Internet for communication and commercial transactions. Hence, the present study used MBA students as the sample, in line with the above studies. The sample of the study consisted of MBA students from two main universities and one prominent institute in Sri Lanka. 
Total of 700 online questionnaires were forwarded to the email accounts of the aforesaid students in first week of June 2017, to collect data from the sample respondents. The first reminder was sent in the third week of June 2017 and the second reminder was sent in the second week of July 2017. 438 respondents returned the questionnaires and among them 130 were rejected due to respondents' lack of experience in online shopping. From a total of 308 questionnaires, 16 incomplete questionnaires were removed at the screening process. Accordingly, 292 completed questionnaires were used to represent the sample.

\section{Data Analysis and Findings}

Data were analyzed using Structural Equation Modeling (SEM) as it allows to measure the mediating effects and complex relationships (Hair et al. 2014; Zheng et al. 2011).As the first step, the data were fed into the SPSS 22.0 version to identify the missing values and outliers. According to the descriptive statistics confirmed that there were no missing values in this study. However, 20 outliers were identified using box plot diagrams, and those were removed from the data set. The remaining 272 responses were then considered for data analysis.

Before drawing the measurement model, testing for assumptions of multivariate analysis were performed. Normality was tested by skewness and kurtosis test which showed that all the values lie between +2 and -2 (Field 2013; George \& Mallery 2003). Scatter plots were used to measure linearity and Homoscedasticity and no deviation was identified. Therefore, transformation or exclusion of data was not required. Finally, multicollinearity was assessed using correlation matrix and all inter-correlation values were less than 0.9 indicating no multicorllinearity issue in the data set.

Since all the multivariate assumptions were satisfied and therefore, the researchers proceeded in to the next stage of analysis with inferential statistics.

\subsection{Structural Equation Modeling}

\subsubsection{Measurement Model}

The measurement model "specifies the indicators for each construct and enables an assessment of construct validity" (Hair et al. 2014, p.544). Therefore, it measures the variables and their associated construct(s). Based on the conceptual model, there are six latent constructs- i.e, Perceived Usefulness (PU), Perceived Ease of Use (PEOU), Website Content (WC), Social commerce constructs (SCC), Trust, and Purchase Intention (PI). For the purpose of confirmatory factor analysis, all the given constructs were allowed to correlate with each other (Byrne 2010).In order to enhance the model fit, modification indices were used and items with standardized factor loadings below 0.5 were removed (Hair et al. 2014). As a result, three items were removed from the measurement model at three stages, and these were SCC4, SCC5 and SCC6. In removing these items, the step wise process was followed, where the item with the lowest factor loading was removed first (Hair et al. 2014).

As per the refined model, it consists of 35 items, and all the standardize factor loadings are above 0.5 and are significant at the 0.05 level of confidence. Accordingly, all of the correlation coefficients are less than 0.9 indicating no signs of multicolinearity among the independent variables in the study (Saunders, Lewis \& Thornhill 2009).

The final measurement model achieved a good level of fit, having a CMIN/DF=2.355, GFI=0.931, CFI=0.941 and RMSEA $=0.071$. Furthermore, Chi-square statistic of 1262.464 with 536 degrees of freedom indicating that the model has an adequate fit.

Reliability was measured using composite reliability (CR) (values $>0.6$ ). Convergent and discriminant validity were assessed using Average Variance Extracted (AVE) (values > 0.5) and Squared Multiple Correlation (SMC) and AVE matrix respectively. As shown in Table 01, all the CR values are greater than 0.6. The AVE values of all the dimensions and constructs are greater than or equal to 0.5 . The values depicted in the diagonal boxes of Table 01, corresponding to each construct represent the square roots of the AVE and the off-diagonal elements represent the SMC. Since all the diagonal elements are greater than the corresponding off-diagonal elements, it can be concluded that the data demonstrates adequate discriminant validity as well. Furthermore, standardized factor loadings of all the dimensions are greater than 0.5 .Hence, the reliability and validity of the measurement model is assured. 
Table 1. Reliability and Validity Summary

\begin{tabular}{lcccccccc}
\hline Variable & CR & \multicolumn{1}{c}{ AVE } & PU & PEOU & WC & SCC & TRUST & PI \\
\hline PU & 0.81 & 0.52 & $\mathbf{0 . 5 2}$ & & & & & \\
PEOU & 0.83 & 0.50 & 0.471 & $\mathbf{0 . 5 0}$ & & & \\
WC & 0.91 & 0.51 & 0.442 & 0.361 & $\mathbf{0 . 5 1}$ & $\mathbf{0 . 6 6}$ & \\
SCC & 0.85 & 0.66 & 0.047 & 0.072 & 0.047 & 0.023 & $\mathbf{0 . 5 9}$ & \\
TRUST & 0.90 & 0.59 & 0.441 & 0.367 & 0.492 & 0.568 & $\mathbf{0 . 6 3}$ \\
PI & 0.90 & 0.63 & 0.448 & 0.358 & 0.436 & 0.014 & 0.568 \\
\hline
\end{tabular}

Note. AVE values are shown in bold.

\subsubsection{Structural Model}

The structural model indicates the hypothesized relationships among the latent variables. Figure 02 presents the results of the structural model and based on the results, hypotheses were tested and presented in Table 2 as a summary.

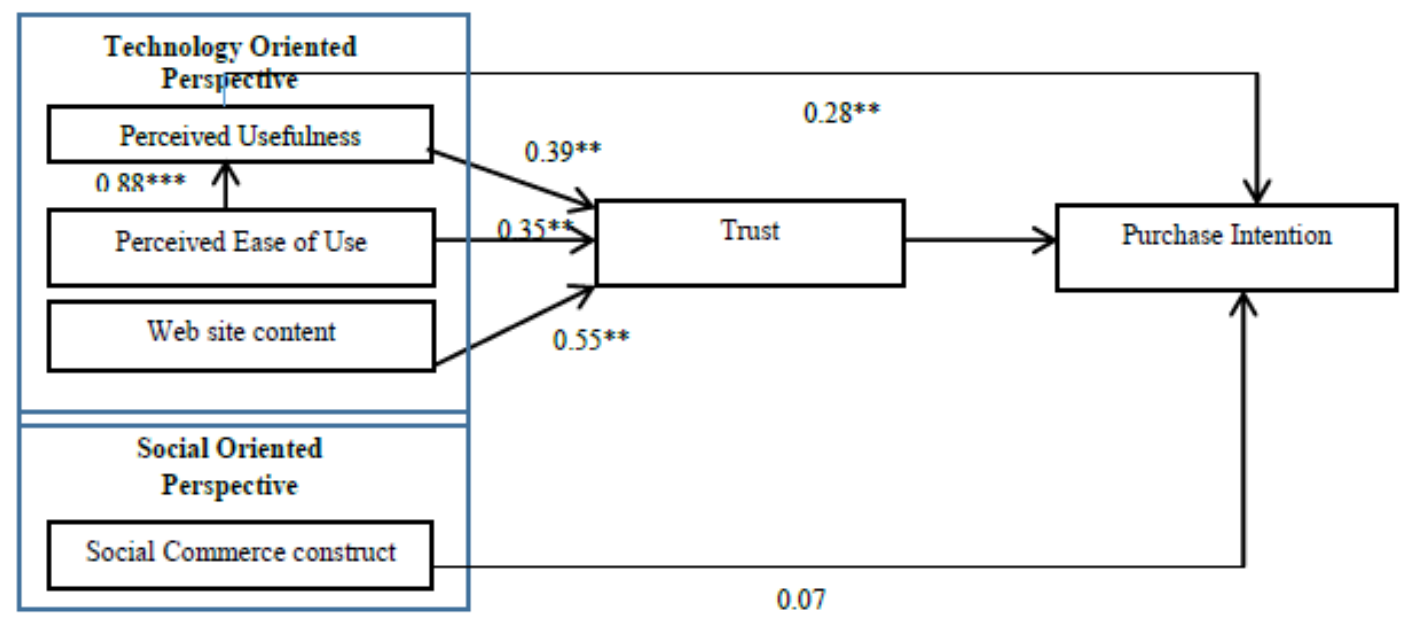

Note. $* * * \mathrm{p}<0.01, * * \mathrm{p}<0.05$

Figure 2. Results of the AMOS analysis

Table 2. Results of the Hypotheses Testing

\begin{tabular}{llll}
\hline Hypothesis & $\boldsymbol{\beta}$ & $\mathbf{P}$ & Result \\
\hline H1: PEOU $\rightarrow$ PU & 0.88 & $0.000^{* * *}$ & Accepted \\
H2:PU $\rightarrow$ PI & 0.28 & $0.005^{* *}$ & Accepted \\
H3:PU $\rightarrow$ TRUST & 0.39 & $0.004^{* *}$ & Accepted \\
H4:PEOU $\rightarrow$ TRUST & 0.35 & $0.001^{* *}$ & Accepted \\
H5:WC $\rightarrow$ TRUST & 0.55 & $0.001^{* *}$ & Accepted \\
H6:SCC $\rightarrow$ PI & 0.07 & 0.127 & Rejected \\
H7:TRUST $\rightarrow$ PI & 0.52 & $0.000^{* * *}$ & Accepted \\
\hline Note. $* * * p<0.01$, & $* * \mathrm{p}<0.05$ & &
\end{tabular}

The structural model achieved a good level of fit, having a CMIN/DF=2.399, GFI=0.911, CFI=0.921 and RMSEA $=0.076$. Therefore it could be concluded that the GOF for the structural model was at an acceptable level.

\subsubsection{Structural Model to Determine Mediating Effect}

Four structural models were drawn to test the mediating effect between relationships. The Bootstrapping method, which has been identified as one of the most powerful methods of testing mediator effects was used in this study (Taylor, MacKinnon \& Tein 2008; Cheung, Chan \& Limayem 2005). Since bootstrapping involves drawing a large number of samples with replacement from the original sample, for the purpose of this study 2000 bootstrap samples were generated at the $95 \%$ confidence level. Table 3 presents the findings of the direct and indirect relationships as well as the mediating effect. 
Table 3. Mediation effect

\begin{tabular}{lllll}
\hline Effect between variables & Direct & Indirect & Total & Mediation effect \\
\hline PU $\rightarrow$ TRUST $\rightarrow$ PI & 0.281 & 0.440 & 0.721 & Partial \\
& $\left(0.004^{* *}\right)$ & $\left(0.001^{* *)}\right.$ & & Mediation \\
\hline PEOU $\rightarrow$ TRUST $\rightarrow$ PI & 0.225 & 0.438 & 0.663 & Full Mediation \\
& $(0.070)$ & $\left(0.001^{* *)}\right.$ & & Full Mediation \\
\hline WC $\rightarrow$ TRUST $\rightarrow$ PI & 0.191 & 0.503 & 0.694 & \\
& $(0.089)$ & $\left(0.001^{* *)}\right.$ & & \\
\hline
\end{tabular}

Note. $* * \mathrm{p}<0.05$

The study has revealed a structural model between PEOU and PI through PU due to the non-significant results of PEOU and PI. Thus the new model is presented below in Figure 3 with the mediation effect included and Table 4 presents the findings of the relationships.

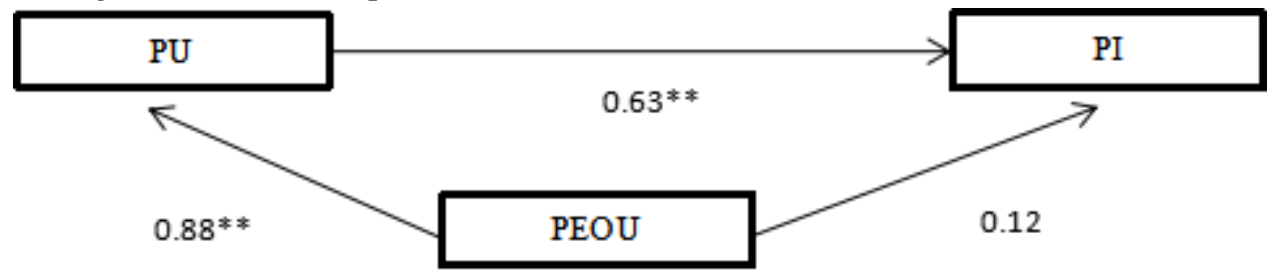

Figure 3. Structural Model for Mediation effect (PEOUàPUàPI)

Note. ${ }^{* *} \mathrm{p}<0.05$

Table 4. Mediating effect PU, in the relationship between PEOU and PI

\begin{tabular}{lllll}
\hline & Direct effect & Indirect effect & Total effect & Mediation effect \\
\hline Path: PEOU $\rightarrow$ PU $\rightarrow$ PI & 0.121 & 0.548 & 0.669 & Full \\
& 0.498 & $0.004^{* *}$ & & Mediation \\
\hline
\end{tabular}

Note. ${ }^{* *} \mathrm{p}<0.05$

\section{Discussion}

Being consistent with the TAM, the study formulated its first four hypotheses as predictors of purchase intention. As shown in Figure 2, PEOU $(\beta=0.88, p<0.01)$ has a strong effect on PU, rendering support for H1. Therefore, there is a strong positive relationship between PEOU and PU. The present finding is consistent with prior findings. According to the modified TAM of Davis (1993), PEOU indirectly influences intention through PU, while, PU directly influences intention. Several other research studies drawn from the e-commerce context also prove the above relationships (Hassanein \& Head 2007; Hsu \& Lu 2004; Gefen \& Straub 2000; Pavlou 2003; Gefen, Karahanna \& Straub 2003). Thus, it has been proved that online shopping should be easy for customers and eventually they will discover its usefulness.

The second hypothesis ( $H 2)$ established between PU and Purchase Intention was supported in the study ( $\beta=0.28$, $\mathrm{p}<0.05)$. Thus, there is a positive relationship between PU and PI. This finding aligns with previous researches as well (Dash \& Saji 2005; Gefen, Karahanna \& Straub 2003; Gefen \& Straub 2000). According to the prior findings of Dash and Saji (2006) there is a direct relationship between PU and purchase intention in B2C online shopping in an Indian context. This relationship established through the path coefficient of the current study is similar to the studies of Pavlou (2003) and Gefen, Karahanna and Straub (2003) which is 0.28. However, the path coefficient established in these studies can be considered to be relatively low compared to the studies by Matute et al. (2016), Shen (2012), Gefen, Karahanna and Straub (2003), who have established path coefficients ranging from 0.40 to 0.51 . The difference in the path coefficients could be due to the differing nature of the category of products being studied (e.g. airline tickets and online retail purchasing).

The third $(\mathrm{H} 3)$ and forth $(\mathrm{H} 4)$ hypothesis too were related to TAM. The findings revealed that the relationship between perceived usefulness and trust is significant $(\beta=0.39, \mathrm{p}<0.05)$ and the relationship between perceived ease of use and trust is also significant $(\beta=0.35, \mathrm{p}<0.05)$. Consequently, both $H 3$ and $H 4$ are supported from the analysis. These findings are also consistent with those obtained in prior research (Gafen et al. 2003; Gefen 2000; Jarvenpaa, Tractinsky \& Vitale 1999; Salisbury et al. 1998). Further, it has been identified that both variables have positive relationships with the Trust. Gafen, Karahanna and Straub (2003)'s findings also showed that PU and PEOU have an impact on trust based on the last online purchase experience.

Website content was also found to have a significant impact on trust $(\beta=0.55, \mathrm{p}<0.05)$, supporting H5. This 
finding too is consistent with prior research (Wen 2009; Chen \& Barnes 2007; Yoon 2002). Similarly, several authors have empirically confirmed that useful and easily understood information reduces information asymmetry and increases online trust and consequently influences purchase intention positively (Cao et al. 2005; Park \& Stoel 2005; Koufaris \& Hampton-Sosa 2004; Kuo et al. 2004). The relationship established through the path coefficient of the study is similar to the one which was established in the study of Ranganathan and Ganapathy (2002).

Analysis revealed that $\mathrm{H} 6$ was not supported $(\beta=0.73, \mathrm{p}>0.05)$. Given the substantial evidence supporting the impact of SCC on purchase intention which was presented in the literature review, this result is quite surprising. However, the recent research findings of Huynh (2012), confirmed that, there was no direct relationship between social networking and online purchase intention. According to the recent research findings (Ayoobkhan 2016), from the Sri Lankan context, it was also revealed that the majority of online customers do not depend on social networks for their actual buying decisions. For that study, data were collected from young people in the eastern parts of Sri Lanka and he summarized that "it is found that young are for the most part dynamic on social media sites, yet with regard to making online purchasing choice, they get to be distinctly inactive" (Ayoobkhan 2016, p.24). Since, the present study too cannot establish a significant relationship between social commerce construct and purchase intention, it may infer that the impact of social commerce attributes on buying behavior is still minimal. Furthermore, nature of items in the questionnaire which were used to measure SCC itself might have contributed to the non-significant relationship. When measuring all other variables, the items in the questionnaire sought the own perception or judgment of the respondent. However, the items used to measure SCC are of different nature. There, the items focuses on how much a respondent depends on someone else's judgment rather than his or her own judgment. Thus, this may point to the requirement of having a different set of items to properly measure SCC.

Finally the relationship established in $H 7$ between Trust and Purchase intention is supported $(\beta=0.52, p<0.01)$ and this finding is consistent with that of prior researches (Li, Kim \& Park 2007; Gefen \& Straub 2000; Gefen, Karahanna \& Straub 2003; Wang 2002; Pavlou 2003). This implies that greater trust towards the online shop generates a greater intention to shop online. The current study has found a relatively strong relationship between trust and purchase intention. In other words, greater consumer trust with regard to the web store would motivate consumers to engage more in online shopping. Therefore, in order to increase the sales of virtual business, web retailers can focus on establishing trust in the customer's mind. Although the degree of the relationship differs to some extent, this study significantly supports the overall relationship between trust and purchase intention. This finding therefore suggests that online shoppers who have favorable attitudes toward a website are more likely to engage in online shopping. In other words, a favorable attitude will lead to online purchase intention.

In addition to that, in the research model of this study, we could find a full mediation of PU in the relationship between PEOU and PI. This is apparently a new contribution to the existing theory. However, the direct relationship between PEOU and PI is not significant $(\beta=0.11, p>0.05)$, which is also consistent with prior findings (Pavlou 2003). As Davis (1989) discussed, perceived ease of use may act indirectly on intention to use through usefulness. The result of the present study is also consistent with prior TAM related research, where researcher found that PU was a more important predictor than PEOU (Hu et al. 1999; Davis 1989). The importance of PU over PEOU has an important implication for website designers. Therefore, when designing a website designers should focus more on the usefulness of the website rather than its ease of use. Similarly, the study has found that PEOU, has a significant impact on trust. When customers feel that website is easy to use, easy to learn, and easy to search for the products they want, they will probably trust that website (Shin, Choo \& Park 2001). Therefore, when designing a website, web designers should focus on the above areas in order to generate trust in the consumer's mind.

\subsection{Implications}

The study is based on the online purchase intention of Sri Lankan customers. There are few studies that have been done in Sri Lankan context in order to find factors affecting online purchase intention and, to the researcher's best knowledge, there is dearth of such research done using SEM analysis. Therefore, the result of this study will be useful to scholars who are interested in this particular area of research.

The study has found a strong relationship between PU, PEOU, website content and trust. These key findings are aligned with prior researches (Jeong, Jeong \& Lee 2006; Gefen 2000; Jarvenpaa, Tractinsky \& Vitale 1999). In addition to that it has revealed that factors have a strong relationship with trust. Therefore, this "Trust" factor is worthwhile to include in future studies as well. The present findings also suggest that TAM is an appropriate model to examine user intention, since PU has shown a significant relationship to purchase intention. 
Since the study has found trust to be a critical factor affecting online purchase intention, it is necessary for web retailers as well as the Sri Lankan government to include trust in their goals when they take strategic decisions. Web retailers could employ different mechanisms in order to establish positive attitudes about trust in customers' minds and consequently attracting shoppers to the web store. Moreover, the proposed model in this study could be used to identify the factors influencing online purchase intention in different cultures. Besides, the significant and positive relationship between website content and trust has important implications for website designers. Website content is one of the key factors affecting online purchase intention, and hence, when designing the website content in the business site, designers should pay particular attention to this factor. In other words, if online retailers can design their store layout with well-organized content it would lead to increase in the purchase intention of their customers.

Furthermore, the present study highlights the importance of technology acceptance, which is identified as an under-researched area in online consumer behavior. Even though many of the marketing researchers discuss the factors affecting online purchase intention, very few have shown the role of technology acceptance and their impact on trust. Therefore the website should be easy for the customers to use and it should be useful for them to full fill their needs and wants. According to the findings, the useful and easy to use websites increase the trust on web retailor and consequently it will lead to increase online purchase intention.

As a whole the findings of the study provides a great message for the online retailers. It gives practical implications for the web retailers as to how to create trust on customers' mind towards the web store and positively influence on online purchase intention. As such web retailers could employ several trust building mechanisms by getting support from the technology to manipulate favorable attitudes on actual consumer buying decisions.

\subsection{Limitations of the Study}

There are a few limitations in this study. Firstly, data were obtained from MBA students. These results may be different from the typical online shoppers. Therefore, generalizability of findings was an issue for many researchers which used similar sample and, this study is also no any exception. However, it is noteworthy that most studies in this context have utilized MBA students as their subject pool (Gefen \& Straub 2000; Grabner-Krauter \& Kaluscha 2003; Walczuch \& Lundgren 2004).

Secondly, the study collected data during a particular time frame and was restricted to five constructs. Besides that, there may be several other factors which influence online purchase intention. Finally, the study was focused to examine factors affecting online retail shopping. Therefore, it was restricted to the business-to-consumer (B2C) model.

\subsection{Directions for Future Research}

The present study was limited to identifying the factors affecting online purchase intention in Sri Lanka. Therefore the study was limited to a particular study context, which is Sri Lanka. Hence, future researchers could use this model to re-examine the factors affecting online purchase intention in different study contexts, especially across cultures, in order to enrich the body of knowledge in this study area.

The area of e-commerce is rich in its variety of settings. The current study was limited to online retail shopping and future research could focus on a variety of settings such as online services (i.e, banking, insurance etc.). The proposed model could be used in the aforementioned settings to determine whether there are any distinguishing factors affecting purchase intention. Similarly, the proposed model could be used to examine purchase intention in different models such as business-to-business (B2B) and consumer- to-consumer (C2C). In other words, other researchers could determine the differences between factors affecting a variety of settings since; the present study was limited to a B2C setting. Constructs were measured by collecting data at a particular time. Therefore, it would be interesting to examine the relationships identified in this research from a longitudinal perspective as well.

\section{Conclusion}

This study particularly investigated the factors affecting online purchase intention from two perspectives; technological oriented perspective and Social oriented perspective. The author borrowed constructs from the technology acceptance model to explain the factors affecting online purchase intention and Trust. Perceived usefulness, perceived ease of use, website content, social commerce constructs and Trust are the main constructs of the proposed model. The study also validates the role and importance of Trust while TAM antecedents and website content affect online purchase intention. The findings reveals that Trust has a mediating effect on perceived usefulness, perceived ease of use and website content on online purchase intention of retail shopping in Sri Lanka. The study also confirmed that there is a positive relationship between Trust and purchase intention 
which is consistent with many other previous researches. However, the findings reveal that social commerce constructs do not influence on purchase intention in Sri Lanka.

\section{References}

Afrasiabi Rad, A., \& Benyoucef, M. (2011). A model for understanding social commerce. Journal of Information Systems Applied Research, 4(2), 63.

Angehrn, A. (1997). Designing mature Internet business strategies: the ICDT model. European Management Journal, 15(4), 361-369. https://doi.org/10.1016/S0263-2373(97)00016-9

Ayoobkhan, A. L. M. (2016). Intention towards Online Shopping Via Social Media Networks: Perspective of Young Generations in the Eastern Parts of Sri Lanka. Journal of Information Systems \& Information Technology (JISIT), 2(1), 18-25.

Bai, Y., Yao, Z., \& Dou, Y. F. (2015). Effect of social commerce factors on user purchase behavior: An empirical investigation from renren. com. International Journal of Information Management, 35(5), 538-550. https://doi.org/10.1016/j.jijinfomgt.2015.04.011

Baloglu, S., Pekcan, Y. A. (2006). The website design and Internet site marketing practices of upscale and luxury hotels in Turkey. Tourism management, 27(1), 171-176. https://doi.org/10.1016/j.tourman.2004.07.003

Bellman, S., Lohse, G.L., \& Johnson, E.J. (1999). Predictors of online buying behavior. Communications of the ACM, 42(12), 32-38. https://doi.org/10.1145/322796.322805

Bhattacharya, R., Devinney, T. M., \& Pillutla, M. M. (1998). A formal model of trust based on outcomes. Academy of management review, 23(3), 459-472. https://doi.org/10.5465/amr.1998.926621

Blackwell, R. D., Miniard, P. W., \& Engel, J. F. (2001). Consumer behavior, 9th edn. South-Western, Mason, $\mathrm{OH}$.

Brown, M., \& Pope, N., \& Voges, K. (2003), Buying or browsing? An exploration of shopping orientations and online purchase intention. European Journal of Marketing, 37(11/12), 1666-1684. https://doi.org/10.1108/03090560310495401

Bukhari, F.A., Rizwan, M., Liaquat, K., Ashraf R, Ali S.M., Azeem, S.R., \& Ali, M.A. (2013). An Investigation of Customers to Explain the Purchase Intentions of Expensive Mobile Phone. Journal of Basic and Applied Scientific Research, 3(11), 87-96.

Byrne, B. M. (2010). Structural equation modeling with AMOS: Basic concepts, applications, \& programming, 2nd edn, Routledge Academy, New York.

Cao, M., Zhang, Q., \& Seydel, J. (2005). B2C e-commerce web site quality: an empirical examination. Industrial Management \& Data Systems, 105(5), 645-661. https://doi.org/10.1108/02635570510600000

Carlos Roca, J., José García, J., \& José de la Vega, J. (2009). The importance of perceived trust, security and Privacy in online trading systems. Information Management \& Computer Security, 17(2), 96-113. https://doi.org/10.1108/09685220910963983

Chen, Y. H., \&Barnes, S. (2007) Initial trust and online buyer behaviour. Industrial management \& data systems, 107(1), 21-36. https://doi.org/10.1108/02635570710719034

Chen, Y., \& Xie, J. (2005). Third-party product review and firm marketing strategy. Marketing Science, 24(2), 218-240. https://doi.org/10.1287/mksc.1040.0089

Cheung, C. M., Chan, G. W., \& Limayem, M. (2005) A critical review of online consumer behavior: Empirical research. Journal of electronic commerce in organizations, 3(4), 1. https://doi.org/10.4018/jeco.2005100101

Chiu, C. M., Wang, E. T., Fang, Y. H., \& Huang, H. Y. (2014). Understanding customers' repeat purchase intentions in $\mathrm{B} 2 \mathrm{C}$ e-commerce: the roles of utilitarian value, hedonic value and perceived risk. Information Systems Journal, 24(1), 85-114. https://doi.org/10.1111/j.1365-2575.2012.00407.x

Colombo Digital Marcket (2007) Internet Usage Statistics in Sri Lanka. http://www.digitalmarketer.lk/Internet-usage-statistics-in-sri-lanka-2016-updated.html

Cooper-Martin, E. (1993). Effects of information format and similarity among alternatives on consumer choice processes. Journal of the Academy of Marketing Science, 21(3), 239-246.

https://doi.org/10.1177/0092070393213007

Corritore, C. L., Marble, R. P., Wiedenbeck, S., Kracher, B., \& Chandran, A. (2005). Measuring online trust of 
websites: Credibility, perceived ease of use, and risk. AMCIS 2005 Proceedings, 370.

Cronin, J. J., Brady, M. K., \& Hult, G. T. M, (2000). Assessing the effects of quality, value, and customer satisfaction on consumer behavioral intentions in service environments. Journal of retailing, 76(2), 193-218. https://doi.org/10.1016/S0022-4359(00)00028-2

Cui, G., Lui, H. K., \& Guo, X. (2012). The effect of online consumer reviews on new productsales. International Journal of Electronic Commerce, 17(1), 39-58. https://doi.org/10.2753/JEC1086-4415170102

Curty, R. G., Zhang, P. (2013). Website features that gave rise to social commerce: a historical analysis. Electronic Commerce Research and Applications, 12(4), 260-279.

https://doi.org/10.1016/j.elerap.2013.04.001

Cyr, D. (2008). Modeling web site design across cultures: relationships to trust, satisfaction, and e-loyalty. Journal of Management Information Systems, 24(4), 47-72. https://doi.org/10.2753/MIS0742-1222240402

Dash, S. B., \& Saji, K. B. (2006). Role of effective Website-Design in online shopping: A large scale empirical study in the Indian Context. Marketing in the New Global Order, Challenges and Opportunities, Excel Books, 435-451.

Davis, F. D. (1989). Perceived usefulness, perceived ease of use, and user acceptance of information technology. MIS Quarterly, 319-340. https://doi.org/10.2307/249008

Davis, F. D. (1993). User acceptance of information technology: system characteristics, user perceptions and behavioral impacts. International journal of man-machine studies, 38(3), 475-487. https://doi.org/10.1006/imms.1993.1022

Droege, S. B., Anderson, J. R., \& Bowler, M. (2003). Trust and organizational information flow. Journal of Business and Management, 9(1), 45.

Field, A. (2013). Discovering statistics using IBM SPSS statistics. Sage.

Flavian, C., Gurrea, R., \& Orús, C., (2009). Web design: a key factor for the website success. Journal of Systems and Information Technology, 11(2), 168-184. https://doi.org/10.1108/13287260910955129

Fukuyama, F. (1995). Trust: The social virtues and the creation of prosperity (No. D10 301 c. 1/c. 2). Free Press Paperbacks.

Ganguly, B., Dash, S. B., Cyr, D., \& Head, M. (2010). The effects of website design on purchase intention in online shopping: the mediating role of trust and the moderating role of culture. International Journal of Electronic Business, 8(4-5), 302-330. https://doi.org/10.1504/IJEB.2010.035289

Gefen, D. (2000), E-commerce: the role of familiarity and trust. Omega, 28(6), 725-737. https://doi.org/10.1016/S0305-0483(00)00021-9

Gefen, D., \& Straub, D. W. (2000). The relative importance of perceived ease of use in IS adoption: A study of e-commerce adoption. Journal of the association for Information Systems, 1(1), 8. https://doi.org/10.17705/1jais.00008

Gefen, D., Karahanna, E., \& Straub, D. W. (2003). Trust and TAM in online shopping: An integrated model. MIS Quarterly, 27(1), 51-90. https://doi.org/10.2307/30036519

Gehrke, D., \& Turban, E. (1999, January). Determinants of successful website design: relative importance and recommendations for effectiveness. In Systems Sciences, 1999. HICSS-32. Proceedings of the 32nd Annual Hawaii International Conference on Systems Sciences.

George, D., \& Mallery, M. (2003). Using SPSS for Windows step by step: a simple guide and reference.

Grabner-Kräuter, S., \& Kaluscha, E. A. (2003). Empirical research in on-line trust: a review and critical assessment. International Journal of Human-Computer Studies, 58(6), 783-812. https://doi.org/10.1016/S1071-5819(03)00043-0

Grange, C., \& Benbasat, I. (2010, January). Online social shopping: The functions and symbols of design artifacts.

Hair, J. F. J., Black, W. C., Babin, B. J., \& Anderson, R. E. (2014). Multivariate Data Analysis 7thEdn. Pearson new international edition. Prentice Hall.

Hajli, M. (2012). An integrated model for e-commerce adoption at the customer level with the impact of social commerce. International Journal of Information Science and Management (IJISM), 77-97. 
Hajli, M. (2013). A research framework for social commerce adoption. Information Management \& Computer Security, 21(3), 144-154. https://doi.org/10.1108/IMCS-04-2012-0024

Hajli, M. N. (2014). The role of social support on relationship quality and social commerce. Technological Forecasting and Social Change, 87, 17-27. https://doi.org/10.1016/j.techfore.2014.05.012

Hassanein, K., \& Head, M. (2007). Manipulating perceived social presence through the web interface and its impact on attitude towards online shopping. International Journal of Human-Computer Studies, 65(8), 689-708. https://doi.org/10.1016/j.ijhcs.2006.11.018

Hausman, A. V., \& Siekpe, J. S. (2009). The effect of web interface features on consumer online purchase intentions. Journal of Business Research, 62(1), 5-13. https://doi.org/10.1016/j.jbusres.2008.01.018

HONG, J. M. T. (2013). The Informavore Shopper: Analysis of Information Foraging, System Design, and Purchasing Behavior in Online Retail Stores. Singapore Management University (Singapore).

Hong, W., Thong, J. Y., \& Tam, K. Y. (2004). The effects of information format and shopping task on consumers' online shopping behavior: A cognitive fit perspective. Journal of management information systems, 21(3), 149-184. https://doi.org/10.1080/07421222.2004.11045812

Hsu, C. L., \& Lu, H. P. (2004). Why do people play on-line games? An extended TAM with social influences and flow experience. Information \& management, 41(7), 853-868. https://doi.org/10.1016/j.im.2003.08.014

Huizingh, E. K. (2000). The content and design of web sites: an empirical study. Information \& Management, 37(3), 123-134. https://doi.org/10.1016/S0378-7206(99)00044-0

Huynh, P. T. (2012). Effects of Web 2.0 experience on consumers' online purchase intention: the Social Networking and Interaction Orientation Factors (Doctoral dissertation, Auckland University of Technology). In System Sciences (HICSS), 2010 43rd Hawaii International Conference on (pp. 1-10). IEEE.

Jarvenpaa, S. L., Tractinsky, N., \& Saarinen, L. (1999). Consumer trust in an Internet store: a cross-cultural validation. Journal of Computer-Mediated communication. https://doi.org/10.1111/j.1083-6101.1999.tb00337.x

Jarvenpaa, S. L., Tractinsky, N., \& Vitale, M. (2000). Consumer trust in an Internet store. Information technology and Management, 1(1-2), 45-71. https://doi.org/10.1023/A:1019104520776

Jascanu, N., Jascanu, V., \& Nicolau, F. (2007). A new approach to E-commerce multi-agent systems.

Jeong, C. H., Jeong, Y. S., \& Lee, K. (2006). Research about the Effects of Internet shopping mall User Trust on Royalty: Comparison Analysis between Korea \& China Trust Determinate Factors. Spring Semi Annual Conferences of KMIS: 659-666.

Kang, J., Tang, L., \& Fiore, A. M. (2014). Enhancing consumer-brand relationships on restaurant Facebook fan pages: Maximizing consumer benefits and increasing active participation. International Journal of Hospitality Management, 36, 145-155. https://doi.org/10.1016/j.ijhm.2013.08.015

Kaplan, A. M., \& Haenlein, M. (2010). Users of the world, unite! The challenges and opportunities of Social Media. Business horizons, 53(1), 59-68. https://doi.org/10.1016/j.bushor.2009.09.003

Keen, P., Ballance, C., Chan, S., \& Schrump, S. (2000). Electronic commerce relationships: Trust by design. Upper Saddle River, NJ: Prentice Hall PTR.

Keller, K. L. (2001). Building customer-based brand equity: A blueprint for creating strong brands (pp. 3-27). Cambridge, MA: Marketing Science Institute.

Khan, H. (2017). A Report on eCommerce Trends in Sri Lanka, daraz.lk, http://www.daraz.lk/research/

Kim, E. B., \& Eom, S. B. (2002). Designing effective cyber store user interface. Industrial Management \& Data Systems, 102(5), 241-251. https://doi.org/10.1108/02635570210428276

Kim, H. W., Xu, Y., \& Koh, J. (2004). A comparison of online trust building factors between potential customers and repeat customers. Journal of the association for information systems, 5(10), 13. https://doi.org/10.17705/1jais.00056

Kim, K. S., Sin, S. C. J., \& Tsai, T. I. (2014). Individual differences in social media use for information seeking. The Journal of Academic Librarianship, 40(2), 171-178. https://doi.org/10.1016/j.acalib.2014.03.001

Kim, Y., \& Srivastava, J. (2007, August). Impact of social influence in e-commerce decision making. In Proceedings of the ninth international conference on Electronic commerce(pp. 293-302). ACM. 
Kotler, P., Armstrong, G., Harris, L., \& Piercy, N. (2005). Principles of marketing. European ed. Financial Times, Harlow.

Koufaris, M. (2002). Applying the technology acceptance model and flow theory to online consumer behavior. Information systems research, 13(2), 205-223. https://doi.org/10.1287/isre.13.2.205.83

Koufaris, M., \& Hampton-Sosa, W. (2004). The development of initial trust in an online company by new customers. Information \& management, 41(3), 377-397. https://doi.org/10.1016/j.im.2003.08.004

Kumar, R., Novak, J., \& Tomkins, A. (2010). Structure and evolution of online social networks. In Link mining: models, algorithms, and applications (pp. 337-357). Springer, New York, NY. https://doi.org/10.1007/978-1-4419-6515-8_13

Kuo, H. M., Hwang, S. L., \& Min-Yang Wang, E. (2004). Evaluation research of information and supporting interface in electronic commerce web sites. Industrial Management \& Data Systems, 104(9), 712-721. https://doi.org/10.1108/02635570410567702

Lederer, A. L., Maupin, D. J., Sena, M. P., \& Zhuang, Y. (2000). The technology acceptance model and the World Wide Web. Decision support systems, 29(3), 269-282. https://doi.org/10.1016/S0167-9236(00)00076-2

Li, R., Kim, J., \& Park, J. (2007). The effects of internet shoppers' trust on their purchasing intention in China. JISTEM-Journal of Information Systems and Technology Management, 4(3), 269-286. https://doi.org/10.4301/S1807-17752007000300001

Liang, T. P., Ho, Y. T., Li, Y. W., \& Turban, E. (2011). What drives social commerce: The role of social support and relationship quality. International Journal of Electronic Commerce, 16(2), 69-90. https://doi.org/10.2753/JEC1086-4415160204

Ling, K. C., Chai, L. T., \& Piew, T. H. (2010). The effects of shopping orientations, online trust and prior online purchase experience toward customers' online purchase intention. International Business Research, 3(3), 63. https://doi.org/10.5539/ibr.v3n3p63

Liu, C., \& Arnett, K. P. (2000). Exploring the factors associated with Web site success in the context of electronic commerce. Information \& management, 38(1), 23-33. https://doi.org/10.1016/S0378-7206(00)00049-5

Lohse, G. L., \& Spiller, P. (1998, January). Quantifying the effect of user interface design features on cyberstore traffic and sales. In Proceedings of the SIGCHI conference on Human factors in computing systems (pp. 211-218). ACM Press/Addison-Wesley Publishing Co. https://doi.org/10.1145/274644.274675

MacCallum, R. C., Widaman, K. F., Zhang, S., \& Hong, S. (1999). Sample size in factor analysis. Psychological methods, 4(1), 84. https://doi.org/10.1037/1082-989X.4.1.84

Marsden, P. (2009). How social commerce works: The social psychology of social shopping. Social Commerce Today. Syzygy London, London.

Matute, J., Polo-Redondo, Y., \& Utrillas, A. (2016). The influence of EWOM characteristics on online repurchase intention: Mediating roles of trust and perceived usefulness. Online Information Review, 40(7), 1090-1110. https://doi.org/10.1108/OIR-11-2015-0373

Mayer, R. C., \& Davis, J. H. (1999). The effect of the performance appraisal system on trust for management: A field quasi-experiment. Journal of applied psychology, 84(1), 123. https://doi.org/10.1037/0021-9010.84.1.123

Mayer, R. C., Davis, J. H., \& Schoorman, F. D. (1995). An integrative model of organizational trust. Academy of management review, 20(3), 709-734. https://doi.org/10.5465/amr.1995.9508080335

McGinity, M. (2000). Surfing your turf. Communications of the ACM, 43(4), 19-19. https://doi.org/10.1145/332051.332061

McKnight, D. H., Kacmar, C. J., \& Choudhury, V. (2004). Shifting Factors and the Ineffectiveness of Third Party Assurance Seals: A two-stage model of initial trust in a web business. Electronic Markets, 14(3), 252-266. https://doi.org/10.1080/1019678042000245263

Metzger, M. J., \& Flanagin, A. J. (2013). Credibility and trust of information in online environments: The use of cognitive heuristics. Journal of Pragmatics, 59, 210-220. https://doi.org/10.1016/j.pragma.2013.07.012

Mithas, S., Ramasubbu, N., Krishnan, M. S., \& Fornell, C. (2006). Designing web sites for customer loyalty 
across business domains: A multilevel analysis. Journal of management information systems, 23(3), 97-127. https://doi.org/10.2753/MIS0742-1222230305

Moon, J. W., \& Kim, Y. G. (2001), Extending the TAM for a World-Wide-Webcontext. Information \& Management, 38(4), 217-230. https://doi.org/10.1016/S0378-7206(00)00061-6

Muir, B. M., \& Moray, N. (1996). Trust in automation. Part II. Experimental studies of trust and human intervention in a process control simulation. Ergonomics, 39(3), 429-460. https://doi.org/10.1080/00140139608964474

$\mathrm{Ng}$, C. S. P. (2013). Intention to purchase on social commerce websites across cultures: A cross-regional study. Information \& Management, 50(8), 609-620. https://doi.org/10.1016/j.im.2013.08.002

Park, D. H., Lee, J., \& Han, I. (2007). The effect of on-line consumer reviews on consumer purchasing intention: The moderating role of involvement. International journal of electronic commerce, 11(4), 125-148. https://doi.org/10.2753/JEC1086-4415110405

Park, J., \& Stoel, L. (2005). Effect of brand familiarity, experience and information on online apparel purchase. International Journal of Retail \& Distribution Management, 33(2), 148-160. https://doi.org/10.1108/09590550510581476

Pavlou, P. A. (2003). Consumer acceptance of electronic commerce: Integrating trust and risk with the technology acceptance model. International journal of electronic commerce, 7(3), 101-134. https://doi.org/10.1080/10864415.2003.11044275

Ranganathan, C., \& Ganapathy, S. (2002). Key dimensions of business-to-consumer web sites. Information \& Management, 39(6), 457-465. https://doi.org/10.1016/S0378-7206(01)00112-4

Raza, M. A., Ahad, M. A., Shafqat, M. A., Aurangzaib, M., \& Rizwan, M. (2014). The Determinants of Purchase Intention towards Counterfeit Mobile Phones in Pakistan. Journal of Public Administration and Governance, 4(3), 1-19. https://doi.org/10.5296/jpag.v4i3.5846

Richard, M. O. (2005). Modeling the impact of Internet atmospherics on surfer behavior. Journal of business research, 58(12), 1632-1642. https://doi.org/10.1016/j.jbusres.2004.07.009

Ridings, C. M., \& Gefen, D. (2004). Virtual community attraction: Why people hang out online. Journal of Computer-mediated communication, 10(1). https://doi.org/10.1111/j.1083-6101.2004.tb00229.x

Roca, J. C., Chiu, C. M., \& Martínez, F. J. (2006). Understanding e-learning continuance intention: An extension of the Technology Acceptance Model. International Journal of human-computer studies, 64(8), 683-696. https://doi.org/10.1016/j.ijhcs.2006.01.003

Rosen, D. E., \& Purinton, E. (2004). Website design: Viewing the web as a cognitive landscape. Journal of Business Research, 57(7), 787-794. https://doi.org/10.1016/S0148-2963(02)00353-3

Sauders, M., Lewis, P., \& Thornhill, A. (2009) Research methods for business students, 5th edn. Pearson Education, India.

Senecal, S., \& Nantel, J. (2004). The influence of online product recommendations on consumers' online choices. Journal of retailing, 80(2), 159-169. https://doi.org/10.1016/j.jretai.2004.04.001

Shankar, V., Urban, G. L., \& Sultan, F. (2002). Online trust: a stakeholder perspective, concepts, implications, and future directions. The Journal of strategic information systems, 11(3-4), 325-344. https://doi.org/10.1016/S0963-8687(02)00022-7

Shen, J. (2012). Social comparison, social presence, and enjoyment in the acceptance of social shopping websites. Journal of Electronic Commerce Research, 13(3), 198.

Shen, J., \& Eder, L. B. (2012). An examination of factors associated with user acceptance of social shopping websites. International Journal of Technology and Human Interaction (IJTHI), 7(1), 19-36. https://doi.org/10.4018/jthi.2011010102

Sheppard, B. H., \& Sherman, D. M. (1998). The grammars of trust: A model and general implications. Academy of management Review, 23(3), 422-437. https://doi.org/10.5465/amr.1998.926619

Shin, K. Y., Choo, G. W., \& Park, T. J. (2001). Determinants of Using Internet shopping malls. Journal of MIS Research, 10(1), 279-301.

Soleimani, M., Danaei, H., Jowkar, A., \& Parhizgar, M. M. (2016). The Effect of Perceived Hedonic Value and Social Commerce Constructs on Social Commerce Intention. Journal of Administrative Management, 
Education and Training, 12, 391-407.

Sultan, F., Urban, G., Shankar, V., \& Bart, I. (2003). Determinants and role of trust in e- business: a large scale empirical study. https://dspace.mit.edu/handle/1721.1/1826

Tajfel, H., \& Turner, J. C. (2004). The social identity theory of intergroup behavior. In J. T. Jost \& J. Sidanius (Eds.), Psychology Press, New York.

Taylor, A. B., MacKinnon, D. P., \& Tein, J. Y. (2008). Tests of the three-path mediated effect. Organizational Research Methods, 11(2), 241-269. https://doi.org/10.1177/1094428107300344

Teo, T. S., Lim, V. K., \& Lai, R. Y. (1999). Intrinsic and extrinsic motivation in Internet usage. Omega, 27(1), 25-37. https://doi.org/10.1016/S0305-0483(98)00028-0

Van der Heijden, H., Verhagen, T., \& Creemers, M. (2003). Understanding online purchase intentions: contributions from technology and trust perspectives. European journal of information systems, 12(1), 41-48. https://doi.org/10.1057/palgrave.ejis.3000445

Venkatesh, V., \& Davis, F. D. (2000). A theoretical extension of the technology acceptance model: Four longitudinal field studies. Management science, 46(2), 186-204. https://doi.org/10.1287/mnsc.46.2.186.11926

Walczuch, R., \& Lundgren, H. (2004). Psychological antecedents of institution-based consumer trust in e-retailing. Information \& Management, 42(1), 159-177. https://doi.org/10.1016/j.im.2003.12.009

Wang, S. L. A. (2002). Customer testimonials and news clips as contextual cues in the consumer cognitive processing of online shopping: how do they build trust and then increase purchase intention? Journal of Promotion Management, 9(1-2), 145-162. https://doi.org/10.1300/J057v09n01_12

Wang, Y. D., \& Emurian, H. H. (2005). An overview of online trust: Concepts, elements, and implications. Computers in human behavior, 21(1), 105-125. https://doi.org/10.1016/j.chb.2003.11.008

Wen, I. (2009). Factors affecting the online travel buying decision: a review. International Journal of Contemporary Hospitality Management, 21(6), 752-765. https://doi.org/10.1108/09596110910975990

Wigand, R. T., Benjamin, R. I., \& Birkland, J. L. (2008, August). Web 2.0 and beyond: implications for electronic commerce. In Proceedings of the 10th international conference on Electronic commerce (p.7). ACM.

Wolfinbarger, M., \& Gilly, M. C. (2003). eTailQ: dimensionalizing, measuring and predicting etail quality. Journal of retailing, 79(3), 183-198. https://doi.org/10.1016/S0022-4359(03)00034-4

Wu, C. S., Cheng, F. F., \& Yen, D. C. (2008). The atmospheric factors of online storefront environment design: An empirical experiment in Taiwan. Information \& Management, 45(7), $493-498$. https://doi.org/10.1016/j.im.2008.07.004

Wu, W. Y., Lee, C. L., Fu, C. S., \& Wang, H. C. (2013). How can online store layout design and atmosphere influence consumer shopping intention on a website?. International Journal of Retail \& Distribution Management, 42(1), 4-24. https://doi.org/10.1108/IJRDM-01-2013-0035

Yao-Hua Tan, W. T. (2000). Toward a generic model of trust for electronic commerce. International journal of electronic commerce, 5(2), 61-74. https://doi.org/10.1080/10864415.2000.11044201

Yoon, S. J. (2002). The antecedents and consequences of trust in online-purchase decisions. Journal of interactive marketing, 16(2), 47-63. https://doi.org/10.1002/dir.10008

Zamrudi, Z., Suyadi, I., \& Abdillah, Y. (2017). The Effect of Social Commerce Construct and Brand Image on Consumer Trust and Purchase Intention. PROFIT (JURNAL ADMINISTRASI BISNIS), 10(1), 1-13.

Zheng, S., Zhang, W., \& Du, J. (2011). Knowledge-based dynamic capabilities and innovation in networked environments. Journal of Knowledge Management, 15(6), 1035-1051. https://doi.org/10.1108/13673271111179352

Zhou, L., Dai, L., \& Zhang, D. (2007). Online shopping acceptance model-A critical survey of consumer factors In online shopping. Journal of Electronic commerce research, 8(1). 


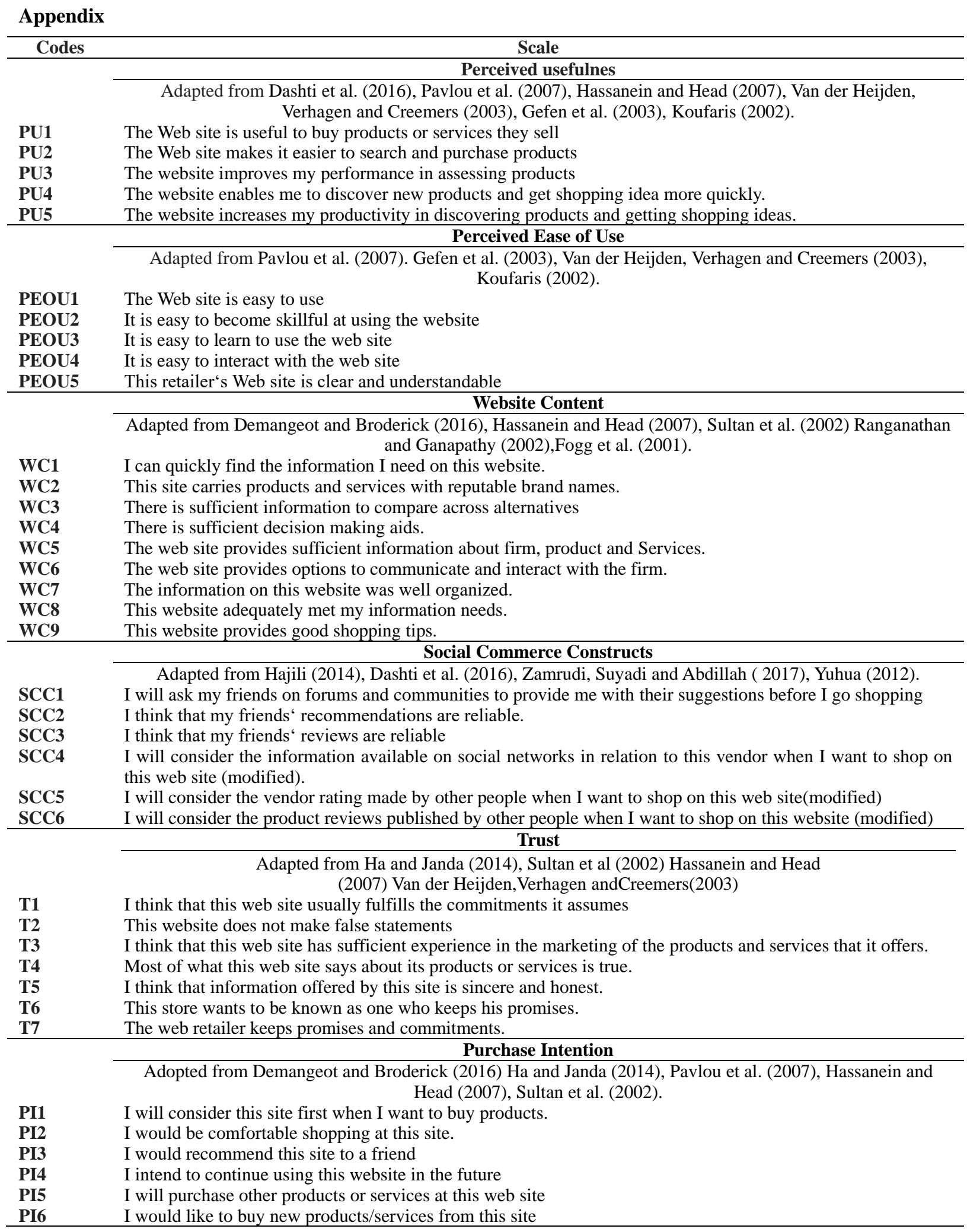

\section{Copyrights}

Copyright for this article is retained by the author(s), with first publication rights granted to the journal.

This is an open-access article distributed under the terms and conditions of the Creative Commons Attribution license (http://creativecommons.org/licenses/by/4.0/). 